\author{
A. Gomes Correia, ${ }^{1}$ António J. Roque, ${ }^{2}$ S. M. Reis Ferreira, ${ }^{3}$ \\ and Eduardo Fortunato 4
}

\title{
Case Study to Promote the Use of Industrial Byproducts: The Relevance of Performance Tests
}

\begin{abstract}
Currently, there is strong pressure to use industrial byproducts and recycled materials in the construction of transportation infrastructure and geotechnical works. The reuse of these materials positively affects the environment by reducing deposits and preserving raw materials. The related geotechnical, geoenvironmental, economical, and social issues should be addressed so that these materials can be used in construction to provide sustainable development. This paper presents a study of all of these aspects and focuses on Portuguese electrical arc furnace steel slag. A huge laboratory research program was carried out that addressed four elements of geotechnical and geoenvironmental behavior: ultimate strength under monotonic loading, resilient behavior (stiffness), susceptibility to permanent deformation due to repeated loading, and leachability. These test results were compared with those from the empirical tests used in the national specifications for embankments and structural layers of transportation infrastructures. It was concluded that performance-based laboratory test results show much better material performance than the results based on empirical tests (Los Angeles and micro-Deval). Furthermore, this material shows better mechanical performance than in the mechanical tests of natural unbound granular materials used in road construction. Additionally, leaching test results show that this byproduct is inert, which caused it to become known as "inert steel aggregates for construction" (ISAC). These laboratory conclusions were validated in a full-scale field trial by end performance testing (using devices that measure in situ stiffness through spot tests and continuous monitoring, as well as lysimeters to measure leaching values). This field trial involved raw materials and ISAC. A final remark is made about some socioeconomic aspects that should be taken into account in decision making regarding the use of ISAC in public works.
\end{abstract}

KEYWORDS: steel slag, natural materials, recycled materials, performance-based tests, index tests, mechanical classification, environmental properties, lysimeter, full-scale field trial

\section{Introduction}

In Portugal, there are two iron steel companies (ISCs). These companies are currently operating with electric arc furnaces. One is located at Paio Pires, Seixal (Seixal ISC), and the other is at S. Pedro de Fins, Maia (Maia ISC). These two Portuguese ISCs produce about 1500000 tons of steel, resulting in 270000 tons of black steel slag. After the metallic component is removed for recycling, 250000 tons of nonmetallic components remain, which are subsequently transformed into inert aggregates. Based on the data provided by the Portuguese ISCs, within a medium term, about 400000 tons of black steel slag are expected to be produced annually.

The management of this large volume of material, in accordance with the applicable legal policies, represents a significant source of concern for the ISCs and for the country. In Portugal, and also at the international level, preventing the production of a significant number of different types of waste is still not feasible. Therefore, a waste management strategy should favor the exploitation of its potential, namely, through reuse solutions. For instance, these materials could be used in the construction of transportation

\footnotetext{
Manuscript received January 6, 2011; accepted for publication January 17, 2012; published online February 2012.

${ }^{1}$ Full Professor, Univ. of Minho, School of Civil Engineering/C-TAC, Campus de Azurem, 4800-058 Guimarães, Portugal, e-mail: agc@civil.uminho.pt

${ }^{2}$ Senior Research Officer, National Laboratory of Civil Engineering, Av do Brasil 101, 1700-066 Lisbon, Portugal, e-mail: aroque@lnec.pt

${ }^{3}$ Ph.D. Student, Univ. of Minho, School of Civil Engineering/C-TAC, Campus de Azurém, 4800-058 Guimarães, Portugal, e-mail: sandraferreira@civil.uminho.pt

${ }^{4}$ Senior Research Officer, National Laboratory of Civil Engineering, Av do Brasil 101, 1700-066 Lisbon, Portugal, e-mail: efortunato@lnec.pt
}

Copyright $@ 2012$ by ASTM International, 100 Barr Harbor Drive, PO Box C700, West Conshohocken, PA 19428-2959. 


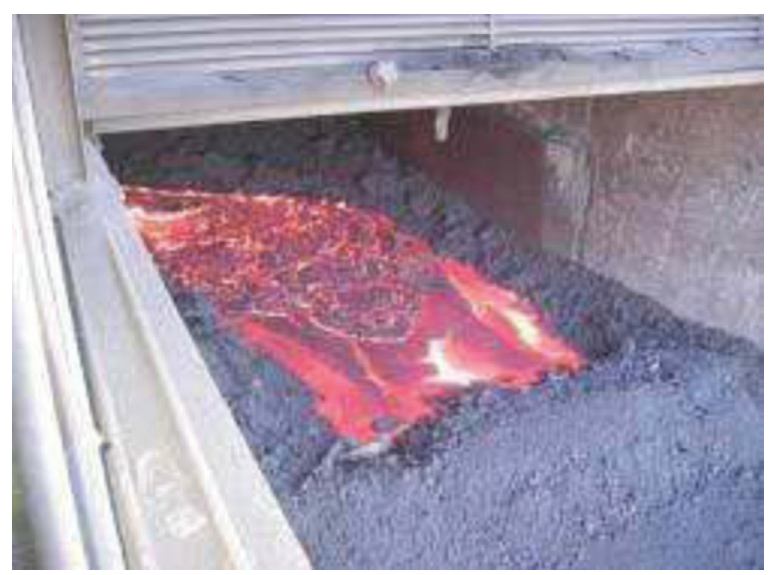

FIG. 1-Emptying of steel slag at the end of the oxidation phase (Roque et al., 2007).

infrastructures and geotechnical works. The implementation of this practice should follow the principles of sustainable development: (i) reducing the quantity of waste that is disposed of in landfills, (ii) creating a new and important national market, and (iii) preserving natural raw materials [1].

According to routine tests and criteria for natural materials, steel slags have, in the past, generally been considered as inappropriate for use in geotechnical works, as have many other non-traditional materials. However, mainly in the past decade, research has been conducted by geotechnical engineers and other scientists hoping to open avenues for steel slag use in construction applications-for example, as a granular material in road base or subbase courses [1-3]. This research has made it possible to use steel slag as a granular base or subbase material in large-scale highway construction [2,4]. Nevertheless, steel slag aggregate has not been extensively used in Portuguese constructions. For this reason, a research and development project was undertaken in Portugal (2005-2009) that was designed to study the reuse of processed steel slag, now renamed inert steel aggregate for construction (ISAC), produced by the Portuguese ISCs.

There is a common understanding that many of the engineering test methods used for natural materials might not predict the true field performance when applied to non-natural materials. For this reason, this national project gave priority to laboratory performance-based tests for engineering properties. It also examined the environmental properties, which are relevant for non-natural materials, and employed field tests to check the laboratory test results. By doing so, this project followed the most relevant recommendations of previous European Community projects [5-7].

In this framework, a huge laboratory research program was carried out that addressed the four main aspects of geotechnical and geoenvironmental behavior: ultimate strength under monotonic loading, resilient behavior (stiffness), susceptibility to the build-up of permanent deformation due to repeated loading, and leachability. The laboratory test results were validated in a full-scale field trial via field tests that addressed the same engineering properties (using devices that measure in situ stiffness with spot tests and continuous

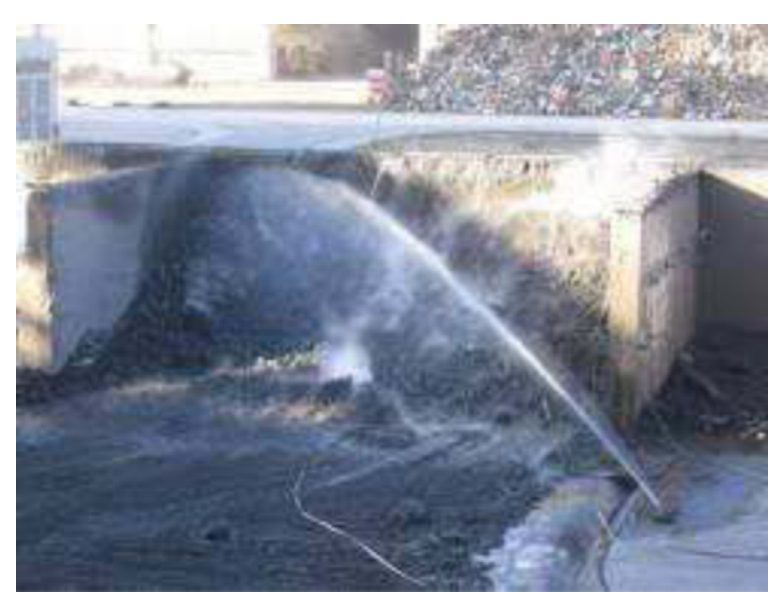

FIG. 2-Cooling of steel slag with water (Roque et al., 2007). 


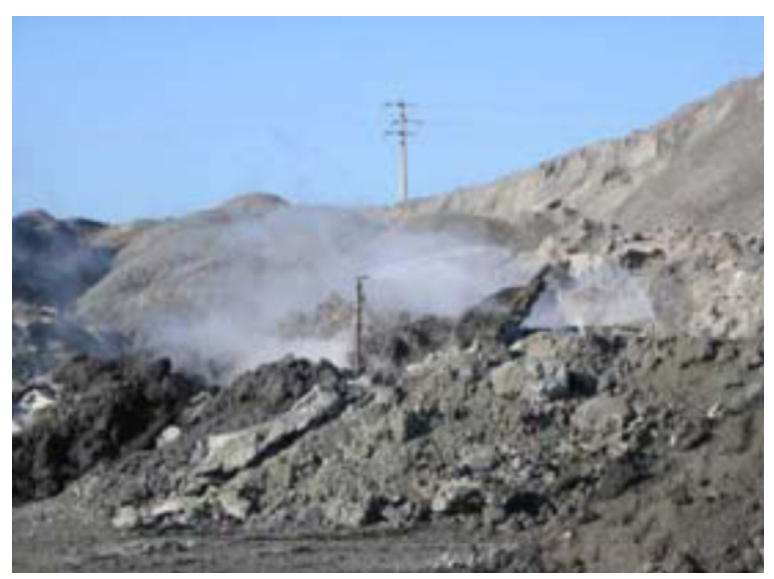

FIG. 3-Cooling of steel slag with air (Roque et al., 2007).

monitoring and lysimeters to measure leaching values). This experimental approach is a sound basis for evaluating the reuse of processed steel slag in transportation infrastructure and geotechnical constructions.

This paper presents a study of all of these aspects and focuses on Portuguese electrical arc furnace steel slag. The test results are compared with those based on the empirical tests used in the national specifications for embankments and structural layers of transportation infrastructures. In addition, this material is compared with that in mechanical tests of natural unbound granular materials used in Portuguese road construction. This work also presents the results obtained from performance-based tests carried out during a full-scale field trial using devices that measure in situ stiffness [namely, a falling weight deflectometer (FWD)] and lysimeters that measure leaching values. A final remark is made concerning some socioeconomic aspects that should be taken into account when deciding whether to use ISAC or other byproducts in public works. These aspects were considered in a road construction case study carried out recently in Portugal.

\section{From Steel Slag to ISAC}

\section{Industrial Process}

In the ISCs with electric arc furnaces, the steel production process has two phases: the fusion phase and the refining phase. The main raw material used in the fusion phase is ferrous scrap iron. The components that produce black steel slag (mainly lime) are also added during this phase. The refining phase has three stages: the first corresponds to the oxidation period, during which the black steel slag is produced; the second corresponds to the reduction period, which produces the black steel slag; and the last corresponds to the final adjustment period of the composition.

Black slag, which is separated from the liquid steel at the end of the oxidation phase and emptied into a steel slag pit (Fig. 1), is processed in order to obtain ISAC as a recycled material to be used in

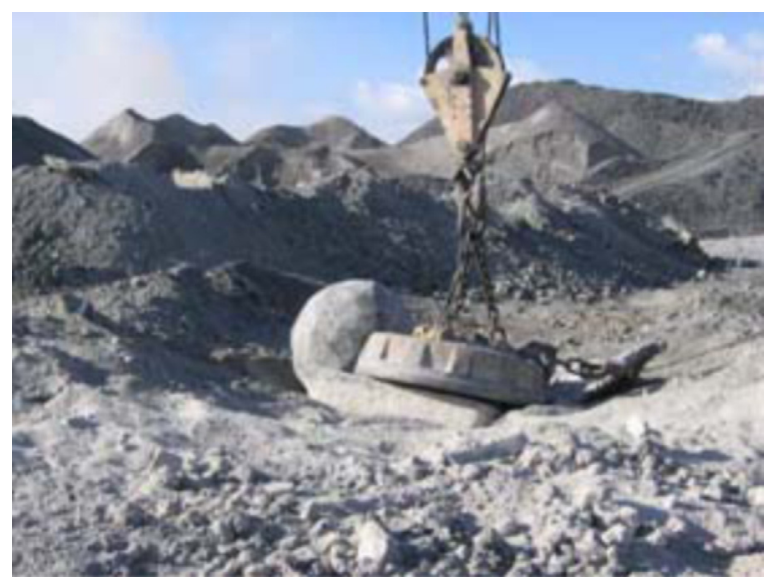

FIG. 4-Breaking up equipment of steel slag (Roque et al., 2007). 


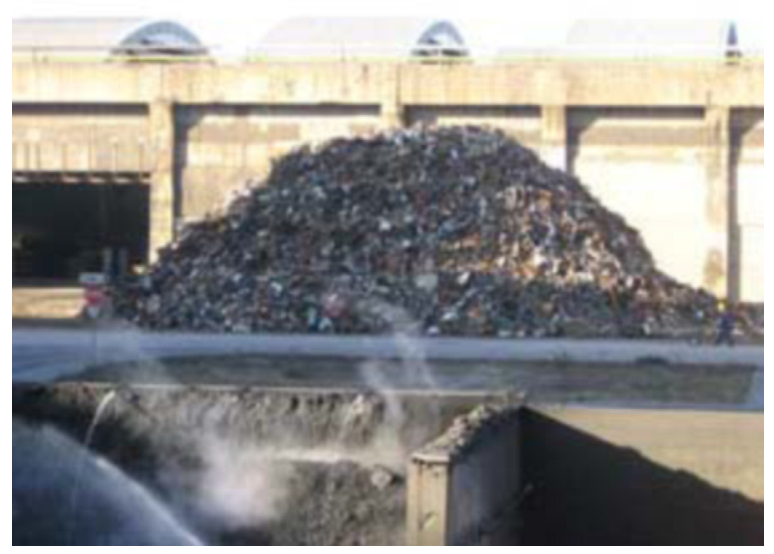

FIG. 5-Metallic parts recovered during processing (Roque et al., 2007).

transportation infrastructure and geotechnical works. The three phases of that process, described in Ref 8 , are summarized below.

Phase A: Flow and cooling of steel slag. A.1: Transferring the steel slag from the pit to an impervious zone, cooling it with water, and transporting it to the storage/treatment zone (see Fig. 2). A.2: Cooling the slag to air temperature at the storage/processing zone, a step that can be accelerated with water (see Fig. 3). The resulting material is designated as non-processed steel slag.

Phase B: Recycling of the metallic component. B.1: Breaking up of the larger steel slag plates and recovering the larger metallic components (see Fig. 4). B.2: Separating the metallic parts from the nonmetallic parts using magnetic drums (see Fig. 5). The metallic parts are to be recycled in the steel production process. Only a small quantity of minor metallic scraps is present in the remaining steel slag.

Phase C: Recycling of the non-metallic component. C.1: Sieving/grading into various grain-size ranges (see Fig. 6). C.2: New mechanical breaking up, with possible grinding, to produce finer grain-sizes. C.3: Elimination of smaller metallic scraps that were not eliminated in the previous phase by passing them by a magnetic plate and/or re-processing or passing the material through a magnetic drum again. C.4: Storage and maturation via hydration to air, ensuring the time necessary to neutralize the remaining lime (Fig. 7).

\section{Laboratory Investigation}

Environmental Properties-The leachability potentials of six specimens of ISAC collected from 3and 6-month maturation piles at ISC Maia were studied. The values presented in Table 1 correspond to the leachability potential of a single specimen of the sample collected from the 3-month maturation pile. The complete leaching values can be found in Ref 9 . When the tests were performed, the applicable Portuguese legislation in force was Decree-law No. 152/2002, 23 May, and therefore the German standard DIN 38414-S4 [10] was adopted rather than the European Standard EN 12457 (Part 2 or Part 4) [11], defined in the Portuguese legislation that is presently in force (Decree-law No. 183/2009, 10 August).

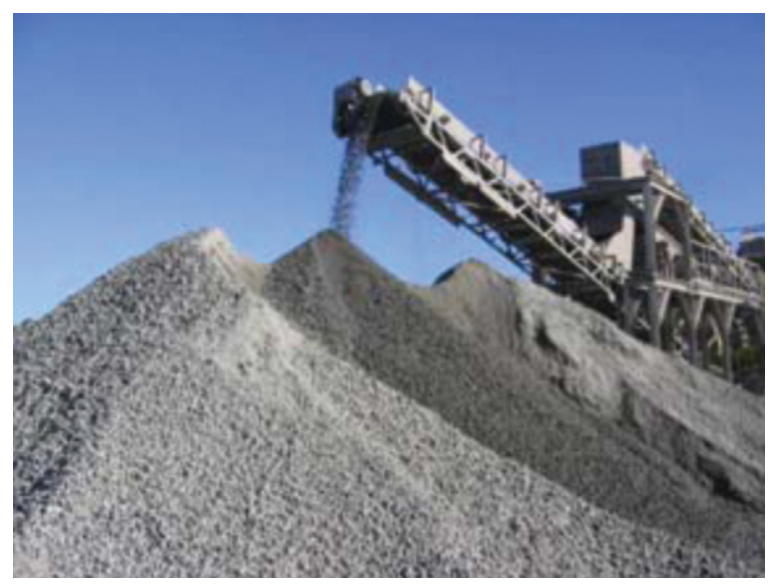

FIG. 6-Classification of the material (Roque et al. 2007). 


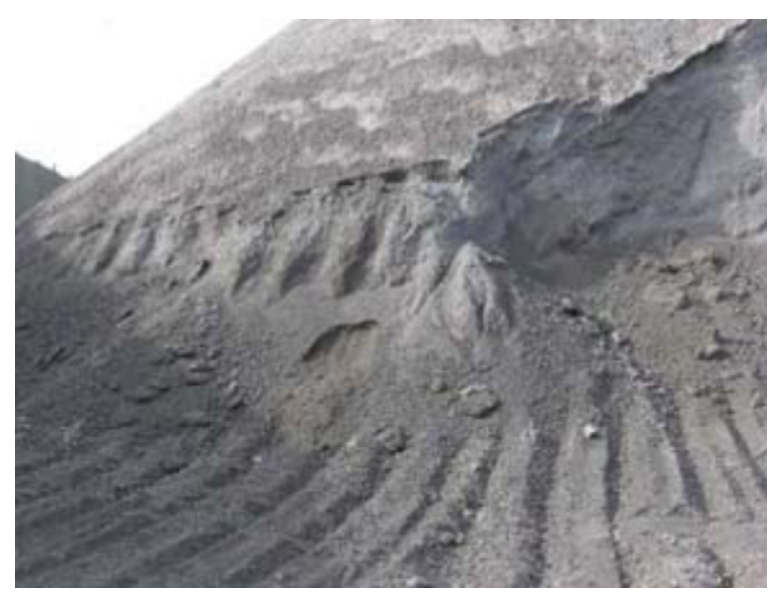

FIG. 7-Storage and maturation by hydration to air (Roque et al. 2007).

When comparing the leaching values obtained with the leaching limit values established in Decreelaw No. 152/2002 for waste admissible in inert waste landfills, it is observed that all elements present have lower values - sometimes significantly lower-than the leaching limit values required. Thus, ISAC is, from a leachability point of view, in accordance with the requirements established in the mentioned legislation, and therefore it is waste admissible for inert waste landfills. The waste included in this class has been approved by the Portuguese Environment Agency for recycling in civil engineering works.

The leaching test results presented in Ref 1 also show that the amount of leached elements from the steel slag tested was insignificant in terms of its environmental impact.

Geotechnical Index Properties-The laboratory study of ISAC started with the current geotechnical test procedures to obtain geometrical, physical, and mechanical index properties. Table 2 summarizes the values found for the Seixal and Maia ISACs.

The sources of the materials were a 6-month maturation pile at ISC Maia (Maia ISAC) and another pile with a grain size in the range of $0-40 \mathrm{~mm}$ in diameter (the maturation time was unknown) at ISC Seixal (Seixal ISAC).

TABLE 1-Chemical composition and classification of the ISAC leachate.

\begin{tabular}{|c|c|c|c|}
\hline Parameter & $\begin{array}{c}\text { Leachate } \\
\text { Composition }\end{array}$ & $\begin{array}{l}\text { Maximum Values in the } \\
\text { Portuguese Legislation for } \\
\text { Waste Admissible in Inert Waste Landfills }\end{array}$ & $\begin{array}{c}\text { Classification } \\
\text { (Decree-Law No. 152/2002) }\end{array}$ \\
\hline $\mathrm{pH}(-)$ & 10.3 & $5.5<x<12$ & Inert \\
\hline Electrical conductivity, $\mathrm{mS} / \mathrm{cm}$ & 0.117 & $6<y<50$ & Inert \\
\hline Ammonium, mg N/l & $<0.13$ & 5 & Inert \\
\hline Adsorbable organic halogens, $\mathrm{mg} \mathrm{Cl} / \mathrm{l}$ & $<0.010$ & 0.3 & Inert \\
\hline Arsenic, mg/l & $<0.0018$ & 0.1 & Inert \\
\hline Cadmium, mg/l & 0.01 & 0.1 & Inert \\
\hline Lead, mg/l & $<0.06$ & 0.5 & Inert \\
\hline Cyanide, mg/l & $<0.05$ & 0.1 & Inert \\
\hline Chloride, $\mathrm{mg} / \mathrm{l}$ & $<3$ & 500 & Inert \\
\hline Copper, mg/l & $<0.025$ & 2 & Inert \\
\hline Carbon organic total, $\mathrm{mg} \mathrm{C} / \mathrm{l}$ & 3.8 & 40 & Inert \\
\hline Chromium VI, mg/l & $<0.05$ & 0.1 & Inert \\
\hline Total chromium, mg/l & $<0.05$ & 0.5 & Inert \\
\hline Phenol, mg/l & $<0.01$ & 1 & Inert \\
\hline Fluoride, mg/l & 0.04 & 5 & Inert \\
\hline Mercury, mg/l & $<0.002$ & 0.02 & Inert \\
\hline Nickel, mg/l & $<0.04$ & 0.5 & Inert \\
\hline Nitrite, mg/l & $<0.04$ & 3 & Inert \\
\hline Sulphate, $\mathrm{mg} / \mathrm{l}$ & $<10$ & 500 & Inert \\
\hline Zinc, mg/l & $<0.008$ & 2 & Inert \\
\hline
\end{tabular}


Most of the test procedures in this study were in compliance with the Portuguese standards/specifications, despite the fact that some European standards were already available.

According to the test results presented in Table 2, both recycled ISACs are well graded, and the fines are non-plastic with a particle density of about 3 . They have similar flakiness and shape indexes and good resistance to fragmentation and abrasion, with Los Angeles (LA) values of 25\% and a micro-Deval (MDe) value of $11 \%$. The compaction test results have high values for the maximum dry density and low values for the optimum water content, referred to as the modified Proctor. The values found for the California bearing ratio are substantially higher than the values specified in the Specification of the Portuguese Road Administration for natural aggregates.

The swelling properties were compliant with the requirements of UNE EN 1744-1 [22]. The test result, available only for Seixal ISAC, was $1.5 \%$ (in volume) lower than the maximum value (5\%) of class V5 specified in European Standard EN 13242 [23]. In fact, this test is performed every year, but the result presented is from 2007, the year of the ISAC sampling for testing.

The data in Table 2 show that Seixal and Maia ISACs have quite similar geotechnical index properties.

Performance-Based Properties-There is a common understanding that many of the current index test methods used for natural materials might not predict true field performance when applied to nontraditional materials. In order to overcome this problem, laboratory performance-based tests are identified as a priority. In this study, the performance-based tests used cover three aspects of geotechnical behavior: ultimate strength under monotonic loading, resilient behavior (stiffness), and susceptibility to the build-up of permanent deformation due to repeated loading.

Ultimate Strength under Monotonic Loading-To study the property of ultimate shear strength of Maia ISAC, monotonic triaxial tests were carried out on large specimens $(150 \mathrm{~mm}$ in diameter and $300 \mathrm{~mm}$ in height) and very large specimens $(300 \mathrm{~mm}$ in diameter and $700 \mathrm{~mm}$ in height). In some tests, given the size of the selected triaxial cells, only a fraction of the material was tested. For the large triaxial cell, the maximum grain size diameter was $19.1 \mathrm{~mm}$ (truncated fraction), and for the very large triaxial

TABLE 2-Index properties of Seixal and Maia ISAC.

\begin{tabular}{|c|c|c|c|c|c|c|}
\hline \multirow[b]{2}{*}{ Property } & \multirow[b]{2}{*}{ Standard/Specification } & & & \multirow[b]{2}{*}{ Parameter } & \multicolumn{2}{|c|}{ ISAC } \\
\hline & & & & & Seixal & Maia \\
\hline \multirow[t]{8}{*}{ Geometrical } & \multirow[t]{6}{*}{ E LNEC 196 [12] } & \multirow{6}{*}{\multicolumn{2}{|c|}{ Grain size }} & Fine boulder ( $60 \mathrm{~mm}<D<200 \mathrm{~mm}), \%$ & 0.0 & 1.5 \\
\hline & & & & Gravel $(2 \mathrm{~mm}<D<60 \mathrm{~mm}), \%$ & 74.0 & 88.5 \\
\hline & & & & Sand $(0.06 \mathrm{~mm}<D<2 \mathrm{~mm}), \%$ & 19.5 & 8.50 \\
\hline & & & & Fines $(D<0.075 \mathrm{~mm}), \%$ & 6.5 & 1.5 \\
\hline & & & & Uniformity coefficient, $\mathrm{Cu}$ & 33.20 & 9.64 \\
\hline & & & & Curvature coefficient, Cc & 4.30 & 1.95 \\
\hline & BS 812 [13] & \multicolumn{3}{|l|}{ Flakiness index, $\%$} & 5 & 10 \\
\hline & BS 812 [13] & \multicolumn{3}{|l|}{ Shape index, \% } & 6 & 7 \\
\hline \multirow[t]{7}{*}{ Physical } & E LNEC 199 [14] & \multicolumn{3}{|c|}{ Sand equivalent, $\%$} & 80 & 100 \\
\hline & NF P 18-592 [15] & \multicolumn{3}{|c|}{ Methylene blue value, $\%$} & 0 & 0 \\
\hline & NP 143 [16] & \multicolumn{3}{|c|}{ Atterberg limits } & NP & NP \\
\hline & \multirow[t]{4}{*}{ NP $581[17]$} & \multirow{3}{*}{\multicolumn{2}{|c|}{ Density of particles }} & Impermeable, $\rho_{\mathrm{i}}, 10^{3} \mathrm{~kg} / \mathrm{m}^{3}$ & 3.31 & 3.45 \\
\hline & & & & Saturated, $\rho_{\mathrm{s}}, 10^{3} \mathrm{~kg} / \mathrm{m}^{3}$ & 3.05 & 3.25 \\
\hline & & & & Dry, $\rho_{\mathrm{d}}, 10^{3} \mathrm{~kg} / \mathrm{m}^{3}$ & 2.94 & 3.17 \\
\hline & & \multicolumn{3}{|l|}{ Water absorption, \% } & 3.87 & 2.59 \\
\hline \multirow[t]{6}{*}{ Mechanical } & E LNEC 197 [18] & Modified Proctor & \multicolumn{2}{|c|}{ Maximum dry density $\rho_{\mathrm{dOPM}}, 10^{3} \mathrm{~kg} / \mathrm{m}^{3}$} & 2.32 & 2.43 \\
\hline & & & \multicolumn{2}{|c|}{ Optimum moisture content $w_{\mathrm{OPM}}, \%$} & 5.00 & 3.45 \\
\hline & E LNEC 237 [19] & \multicolumn{3}{|l|}{ Los Angeles, \% } & 23 & 28 \\
\hline & NP EN 1097-1 [20] & \multicolumn{3}{|l|}{ Micro-Deval, \% } & 11 & 11 \\
\hline & E LNEC 198 [21] & \multicolumn{3}{|c|}{ California bearing ratio, $\%$} & 100 & 72 \\
\hline & UNE EN 1744-1 [22] & \multicolumn{3}{|c|}{ Expansibility, \% } & 1.5 & ND \\
\hline
\end{tabular}

Note: $\mathrm{NP}=$ non-plastic; $\mathrm{ND}=$ not determined. 
TABLE 3-Confining stresses and state conditions of triaxial specimens to study the ultimate strength.

\begin{tabular}{lcccc}
\hline Material & $\sigma_{3},{ }^{\mathrm{a}} \mathrm{kPa}$ & $\rho_{\mathrm{d}},{ }^{\mathrm{b}} 10^{3} \mathrm{~kg} / \mathrm{m}^{3}$ & $e_{0}{ }^{\mathrm{c}}$ & \\
\hline Truncated & 100 & 2.48 & 0.314 & 3.6 \\
& 200 & 2.43 & 0.339 & 3.5 \\
& 300 & 2.44 & 0.338 & 3.5 \\
Integral & 100 & 2.37 & 0.380 & 3.0 \\
& 200 & 2.35 & 0.390 & 3.0 \\
& 300 & 2.34 & 0.400 & 3.0 \\
\hline
\end{tabular}

${ }^{\mathrm{a}} \sigma_{3}$, confining pressure.

${ }^{\mathrm{b}} \rho_{\mathrm{d}}$, dry density.

${ }^{\mathrm{c}} e_{0}$, initial void ratio.

$\mathrm{d}_{w}$, water content.

cell, the maximum grain size was $50.8 \mathrm{~mm}$. Table 3 summarizes the state conditions of the compacted specimens, as well as the applied stresses.

The peak resistance values were an internal friction angle $(\phi)$ of $39^{\circ}$ and a cohesion (c) of $195.7 \mathrm{kPa}$ for the integral material, and $\phi=42.5^{\circ}$ and $\mathrm{c}=227.6 \mathrm{kPa}$ for the truncated material. The critical state friction angle was around $47^{\circ}$. These high values for the friction angles are consistent with those found in the literature [7].

Elastic Young's Moduli-The elastic Young's moduli were determined through precision triaxial tests carried out on specimens $150 \mathrm{~mm}$ in diameter and $300 \mathrm{~mm}$ in height. The specimens were compacted in 6 layers by a vibrating hammer with a static weight of around $7 \mathrm{~kg}$ and a plate of $146 \mathrm{~mm}$. The time of vibration was necessary in order to achieve, approximately, the same dry density found by the modified Proctor curves. The decision to compact the specimens to a very dense state was made because this is representative of typical compacted pavement layers. The state conditions of studied specimens are shown in Table 4. The same table presents the results for standard base course materials (granite aggregate 0/31.5, granite aggregate 0/19, and limestone aggregate 0/19) that are used for moduli comparison purposes.

In the precision triaxial test available at the Civil Engineering Laboratory of the University of Minho, the axial and radial strains were locally measured using three vertical local deformation transducers (LDTs) [24] and one horizontal LDT. All the LDTs were manufactured at the University of Minho. A standard pressure transducer and a sensitive load cell located inside the triaxial cell are used to measure the boundary stresses (cell and deviatoric stresses). The interstitial air in the material specimen is at the atmospheric pressure through the drainage system. More details of the equipment can be found in Ref 25 .

The test procedure to obtain the material Young's modulus uses several stresses. For each confining pressure $(100,200$, and $300 \mathrm{kPa})$, after consolidation, the test starts with a deviatoric loading applied up to around $1 \times 10^{-3}$ of axial strain, in order to obtain the decay curve of the secant Young's modulus with vertical strain. The strain rate of the test is approximately $0.03 \mathrm{~mm} / \mathrm{min}$. During the unloading process, very small unloading/reloading cycles of vertical stress were performed at different steps (approximately at the maximum value of the deviatoric stress $\left(q_{\max }\right)$ applied to the specimen, at $q_{\max } / 2$ and $\left.q=0 \mathrm{kPa}\right)$. For each step, five unloading/reloading cycles of small vertical stress amplitude were applied. The amplitude was controlled so as to ensure that the cycles were closed and linear, in order to evaluate the elastic Young's modulus.

TABLE 4-Specimen state conditions tested by precision triaxial test.

\begin{tabular}{lccc}
\hline Material & $\rho_{\mathrm{d}}{ }^{\mathrm{a}} 10^{3} \mathrm{~kg} / \mathrm{m}^{3}$ & $e_{0}{ }^{\mathrm{b}}$ & $w,{ }^{\mathrm{c}} \%$ \\
\hline Seixal ISAC & 2.31 & 0.330 & 5.8 \\
Maia ISAC & 2.43 & 0.343 & 3.5 \\
Granite aggregate $(0 / 31.5)$ & 2.19 & 0.236 & 3.9 \\
Granite aggregate $(0 / 19)$ & 2.10 & 0.260 & 5.9 \\
Limestone aggregate $(0 / 31.5)$ & 2.13 & 0.232 & 3.9 \\
\hline
\end{tabular}

${ }^{\mathrm{a}} \rho_{\mathrm{d}}$, dry density.

${ }^{\mathrm{b}} e_{0}$, initial void ratio.

${ }^{c} w$, water content.

Cloxyright by ASTM Int'l (all rights reserved); Thu Sep 27 13:49:25 EDT 2012 
Based on previous findings [26], the very small strain vertical Young's modulus $(E)$ is fitted by a power law with the vertical stress $\sigma_{1}$. The results have been analyzed in total stresses and the values normalized for a stress $\left(p_{a}\right)$ value of $100 \mathrm{kPa}$. The power laws to describe the behavior of Maia ISAC and Seixal ISAC are given by Eq 1 and Eq 2, respectively

$$
\begin{aligned}
& E=737\left(\frac{\sigma_{1}}{p_{a}}\right)^{0.55} \\
& E=833\left(\frac{\sigma_{1}}{p_{a}}\right)^{0.59}
\end{aligned}
$$

The total stress analysis leads to a power $(n)$ equal to 0.59 and 0.55 for Seixal and Maia ISAC, respectively. These power values are similar to the usual values found for natural materials, which normally are approximately 0.5 . These equations also show that the values found for the elastic modulus are high (around $1 \mathrm{GPa}$ for a vertical stress of around $150 \mathrm{kPa}$ ). This result reveals the excellent mechanical behavior (stiffness) of the ISAC being studied.

Susceptibility to the Build-up of Permanent Deformation-The susceptibility to the build-up of permanent deformation was evaluated only for the Maia ISAC via a precision cyclic triaxial test carried out on specimens $150 \mathrm{~mm}$ in diameter and $300 \mathrm{~mm}$ in height. For the precision triaxial tests performed to evaluate the stiffness of the material, the axial and radial strains were measured using vertical and horizontal LDTs, and the specimens were compacted into 6 layers by a vibrating hammer.

The test procedure to obtain the susceptibility to the build-up of permanent deformation followed the test protocol described in European Standard EN 13289-7 [27] for a constant confining pressure at high stress levels. In this paper, only the results obtained in the first phase of the test during cyclic conditioning are reported. This phase consists of the application of a large number of cycles (20 000 cycles) with a high stress level, and a maximum cyclic deviatoric stress $\Delta q$ of $340 \mathrm{kPa}$ and a constant confining pressure $\sigma_{3}$ $(=p)$ of $70 \mathrm{kPa}$. The test was performed on one specimen with a dry density of $2370 \mathrm{~kg} / \mathrm{m}^{3}$ and a water content of $1.8 \%$. With this test protocol, it is possible to determine the value of the characteristic axial permanent strain $\varepsilon_{1 c}$, which defines a parameter relating material resistance to permanent strain. $\varepsilon_{1 c}$ is determined by Eq 3, in which $\varepsilon_{1 p}(20000)$ is the accumulated permanent axial strain at the end of the 20000 cycles of the conditioning phase and $\varepsilon_{1 p}(100)$ is the accumulated permanent axial strain in the first 100 cycles

$$
\varepsilon_{1 c}=\varepsilon_{1 p}(20000)-\varepsilon_{1 p}(100)
$$

Based on the conditioning phase, a value of $6.98 \times 10^{-4}$ was obtained for the characteristic axial permanent strain. This value is small, which means that Maia ISAC has little susceptibility to the build-up of permanent deformation.

\section{ISAC as a Recycled Material for Pavement Layers}

\section{Comparison of ISAC Classifications Based on Performance-Based Properties and Index Properties}

The empirical classification to rank unbound granular materials (road aggregates) in France is Standard XP P 18-540 [28]. This classification ranks natural aggregates according to the values obtained in the LA and MDe tests (index tests). According to this French standard, the unbound aggregates can be classified into five classes, with class A (low values of LA and MDe) including materials with better mechanical properties and class $\mathrm{F}$ including materials with the poorest mechanical properties. Table 5 presents the maximum allowable LA and MDe values for each class. According to this French classification, Maia ISAC belongs to class $\mathrm{C}$ and Seixal ISAC belongs to class B. With this empirical classification, it is expected that Seixal ISAC will demonstrate better performance than Maia ISAC. 
TABLE 5-Unbound aggregate classification by mechanical index tests (XP P 18-540, 1990).

\begin{tabular}{lccc}
\hline & \multicolumn{2}{c}{ Maximum Values } \\
\cline { 2 - 4 } Class & LA & MDe & LA + MDe \\
\hline A & 20 & 15 & 30 \\
B & 25 & 20 & 35 \\
C & 30 & 25 & 45 \\
D & 35 & 30 & 55 \\
E & 45 & 45 & 80 \\
F & ND & ND & ND \\
\hline
\end{tabular}

Note: $\mathrm{ND}=$ not defined.

Based on studies reported in Ref 29, in which 14 natural aggregates were studied through cyclic triaxial tests, a French standard was issued presenting a classification for unbound granular materials. This French standard, NF P98-129 [30], was the main basis for European Standard EN 13286-7 [31], which proposed a classification to rank the mechanical performance of aggregates based on the values of the characteristic modulus $E c$ and the characteristic axial permanent strain $\varepsilon_{1 c}$ obtained for a characteristic stress path. Furthermore, these two parameters $\left(E c\right.$ and $\left.\varepsilon_{1 c}\right)$ are obtained for a compacted material with a moisture content equal to the optimal water content of less than $2 \%$ and a dry density equal to $97 \%$ of the maximum value of the modified Proctor test.

Based on the values found for $E c$ and $\varepsilon_{1 c}$, three classes of mechanical performances, C1 to C3 (see Table 6), were defined. The aggregate with better mechanical performance is the one that has a higher stiffness and a lower susceptibility to the build-up of permanent strain $(\mathrm{C} 1)$.

The cyclic triaxial test results obtained for Maia ISAC (the only material studied) show a value of $6.98 \times 10^{-4}$ for the characteristic axial permanent strain and a value of $720 \mathrm{MPa}$ for the characteristic modulus. According to these values, the Maia ISAC belongs to class C1 [31], which means that this recycled material has excellent mechanical properties. This material has better mechanical properties when evaluated via performance-based tests than when index tests are used, corroborating previous findings and stressing the priority of moving to performance-based tests.

\section{Comparison of Performance-Based Properties of ISAC and Natural Unbound Granular Materials}

The moduli results of ISAC are compared with three standard road base course materials (granite aggregate $0 / 31.5$, granite aggregate $0 / 19$, and limestone aggregate $0 / 19$ ).

The results presented for granite aggregate 0/31.5 were obtained from Ref 32 . The authors of that work studied the modulus of the natural material by means of a relatively large triaxial apparatus with a square prismatic specimen $(230 \mathrm{~mm}$ wide by $580 \mathrm{~mm}$ long). Axial and lateral strains were measured with LDTs. The results presented for granite aggregate 0/19 were obtained from Ref 33, and the limestone aggregate results were obtained from Ref 34 . The authors of those works studied the modulus of the natural materials by means of a triaxial apparatus with a specimen $150 \mathrm{~mm}$ in diameter and $300 \mathrm{~mm}$ in height. Axial and lateral strains were also measured with LDTs.

In order to proceed with the comparison, the test results of the four materials were all normalized for the same void ratio value $e=0.35$. For the normalization, Eq 4 was used, in which $f(e)$ is the void ratio

TABLE 6-Classes of mechanical performance specified by NF P98-129 [30] and EN 13286-7 [31].

\begin{tabular}{|c|c|c|c|c|}
\hline \multirow[b]{2}{*}{ Class } & \multicolumn{2}{|c|}{ NF P98-129 } & \multicolumn{2}{|c|}{ EN 13286-7 } \\
\hline & $E c, \mathrm{MPa}$ & $\varepsilon_{1 c}\left(\times 10^{-4}\right)$ & $E c, \mathrm{MPa}$ & $\varepsilon_{1 c}\left(\times 10^{-4}\right)$ \\
\hline $\mathrm{C} 1$ & $E c \geq 500$ & $\varepsilon_{1 c} \leq 100$ & $E c \geq 500$ & $\varepsilon_{1 c} \leq 25$ \\
\hline \multirow[t]{2}{*}{$\mathrm{C} 2$} & $E c \geq 500$ & $100 \leq \varepsilon_{1 c} \leq 150$ & $E c \geq 500$ & $25 \leq \varepsilon_{1 c} \leq 60$ \\
\hline & $300 \leq E c \leq 500$ & $\varepsilon_{1 c} \leq 150$ & $250 \leq E c \leq 500$ & $\varepsilon_{1 c} \leq 60$ \\
\hline \multirow[t]{2}{*}{$\mathrm{C} 3$} & $E c \geq 300$ & $150 \leq \varepsilon_{1 c} \leq 200$ & $E c \geq 250$ & $\varepsilon_{1 c} \geq 60$ \\
\hline & $120 \leq E c \leq 300$ & $\varepsilon_{1 c} \leq 200$ & & \\
\hline $\mathrm{C} 4$ & $E c \geq 120$ & $\varepsilon_{1 c} \geq 100$ & NA & - \\
\hline
\end{tabular}

Note: $\mathrm{NA}=$ not applicable. 


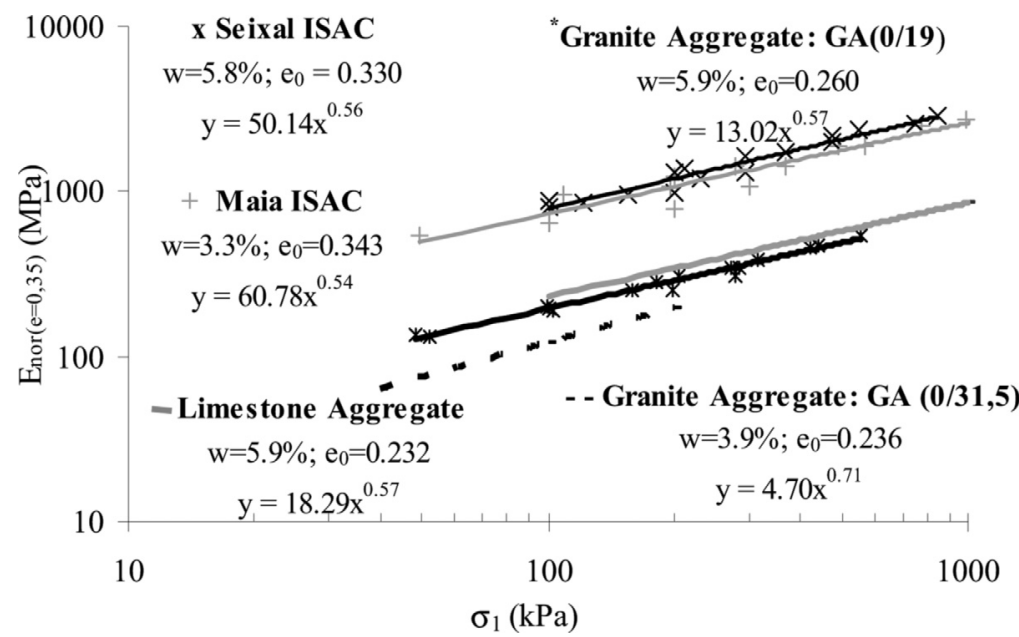

FIG. 8-Relationship between the modulus and the vertical stress for ISAC and for standard base course materials.

function and $E^{*}$ is the value measured in the specimen. The void ratio function used was proposed in Ref 35 and is shown in Eq 5

$$
\begin{gathered}
E=E^{*} \frac{f(0.35)}{f(e)} \\
f(e)=\frac{(2.17-e)^{2}}{1+e}
\end{gathered}
$$

Figure 8 shows the results obtained for the elastic modulus as a function of total vertical stress after void ratio normalization. The values found for ISAC are around four times higher than for granite aggregate $(0 /$ 31.5), which reveals that the ISAC being studied has much better mechanical properties than standard base course materials.

Figure 9 shows the classification of the same materials based on the results of performance-based tests [31]. The same figure also presents the values obtained for a steel slag, a limestone aggregate, and construction and demolition waste (RCD), which are presented in Ref 36. The characteristic modulus and characteristic axial permanent strain presented in Ref 26 were also determined via cyclic triaxial tests with a constant confining pressure $\Delta q=400 \mathrm{kPa}$ and $p=233 \mathrm{kPa}$.

Figure 9 shows that the Maia ISAC and the other two non-natural materials (steel slag and RCD) demonstrate better mechanical behavior than natural aggregates. This finding emphasizes once more the conflict between ranking classifications of aggregates based on index tests (MDe and LA) and on performance-based tests.

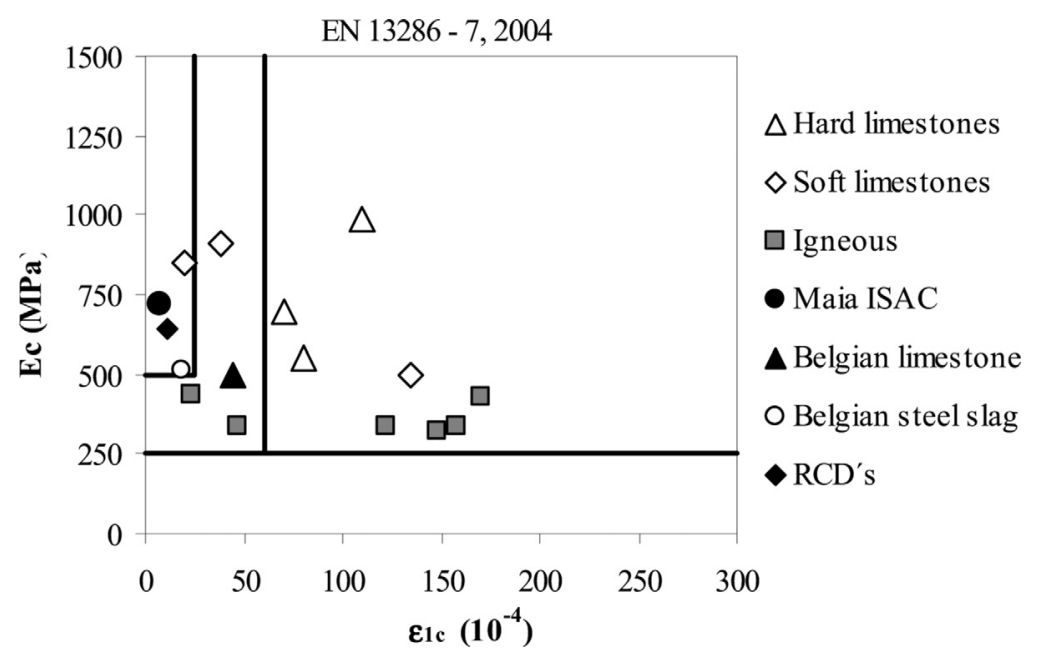

FIG. 9-Comparison of mechanical rankings of ISAC and natural unbound granular materials according to performance-based properties. 


\section{Field Evaluation}

\section{Full-Scale Field Trial}

An assessment of the mechanical and environmental performance of the materials was carried out in a full-scale field trial on three different sections of construction of National Highway EN 311, linking Fafe to Cabeceiras de Basto, to the north of Oporto $(<100 \mathrm{~km})$. The test section was about $60 \mathrm{~m}$ in length and $3 \mathrm{~m}$ in height and was integrated into the national road in use at kilometer $13+600$ of National Highway EN 311. In one section, only natural materials were used (in the embankment, capping, and base layers of the pavement); in a second section, only ISAC was used (in the embankment, capping, and base layers of the pavement); and in the third section, granitic residual soil was used in the embankment and the capping layers of the pavement, and ISAC was used in the base layer. The longitudinal cross-section of the fullscale field trial presented in Fig. 10 shows the three different sections.

The assessment of pavement performance was done using tests with a FWD. The assessment of the environmental performance was carried for a year by means of two lysimeters, one located in the section built with ISAC and another in the section built with granite residual soil (GRS). The GRS lysimeter is used as a reference in the environmental monitoring. Figure 11 shows its location in the full-scale field trial, both in plane and in cross-section.

The dimensions of the ISAC leaching column in the lysimeters corresponded to $2.0 \mathrm{~m} \times 1.0 \mathrm{~m} \times 1.4 \mathrm{~m}$ (length, width, height); the leachate reception basin was installed in the second layer of the full-scale field trial. Figure 12 shows the lysimeters in the national road in two of the sections and a schematic representation of these lysimeters.

\section{Environmental Assessment}

The collected leachate in the section with ISAC was mainly produced by feeding the lysimeter with water from a truck-mounted water tank. This was possible because of the high hydraulic conductivity of ISAC, which made it possible to substantially reduce the time necessary for producing a significant amount of leachate. The remaining leachate was the result of rainwater. However, in the section with GRS, the low hydraulic conductivity permitted feeding of the lysimeter only with rainwater. During leaching, the leachate produced outside the lysimeter column was assumed to have negligibly contributed to the feeding of the reception basin.

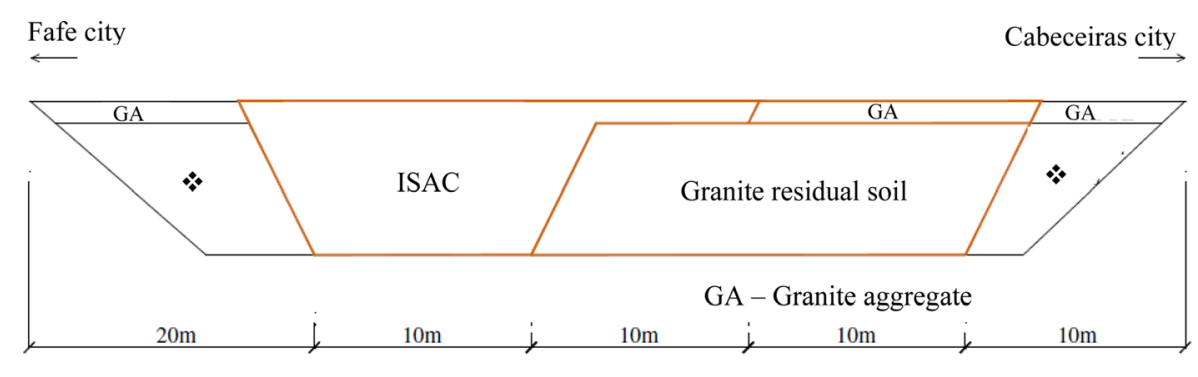

FIG. 10—Longitudinal profile of the full-scale field trial.

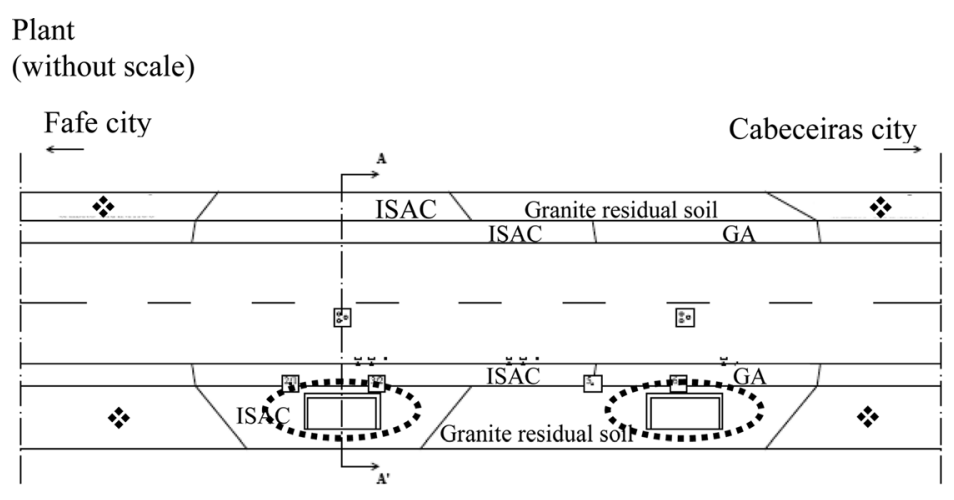

Profile A-A'

(without scale)

(without scale)
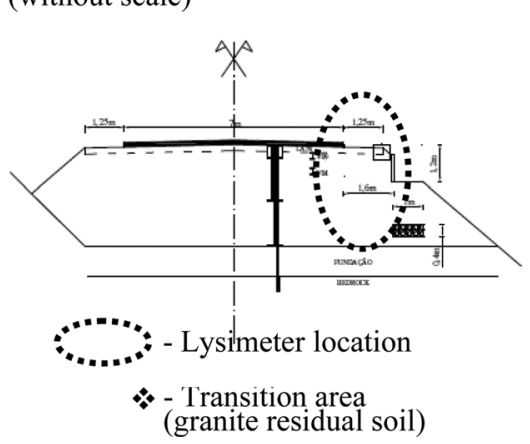

FIG. 11-Location of the lysimeters in the full-scale field trial. 


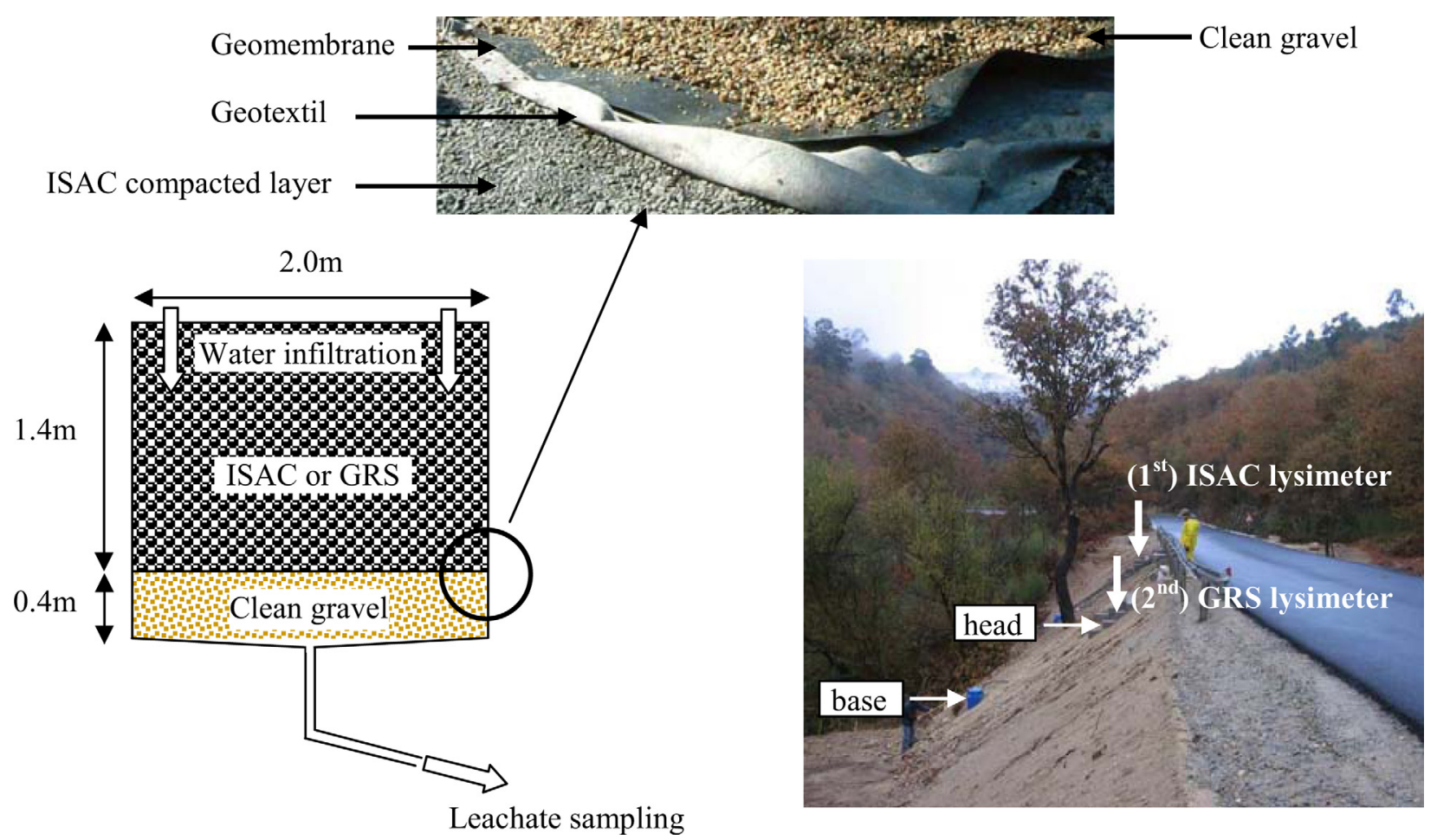

FIG. 12-Lysimeters in the full-scale field trial and schematic representation of these lysimeters.

The leaching values obtained for the 11 samples collected in the ISAC lysimeter are presented in Table 7, along with the same parameters from the laboratory tests. ISAC samples $1-5,7$, and 8 were collected when the lysimeter was fed water from the truck-mounted water tank. ISAC samples 6 and 9-11 were collected when the lysimeter was fed rainwater. The water from the truck-mounted water tank was also collected for chemical analysis and background element concentrations. For economic reasons, a criterion was adopted that, in general, did not involve the determination of all parameters for all samples. Therefore, it was decided that all the elements with concentrations below the quantification limit of the method used would not be subject to dosage.

The results obtained were compared with the leaching limit values established by Decree-Law No. $152 / 2002$. Nonetheless, in this analysis, it is necessary to make sure that the leaching limit values laid down in the legislation have actually been defined for the leach test performed in the laboratory, in accordance with DIN 38414-S4 [10], and that the liquid $(L) /$ solid $(S)$ ratio defined in that standard corresponds to $101 / \mathrm{kg}$, i.e., that it is substantially higher than the one observed in the lysimeter. Even in the sample with the lowest $L / S$ ratio (ISAC 1 , with $L / S=0.05 \mathrm{l} / \mathrm{kg}$ ), which is much lower than the laboratory test ratio $(L /$ $S=101 / \mathrm{kg}$ ), it is observed that the leaching values are lower-sometimes significantly lower-than the leaching limit values established in Decree-Law No. 152/2002, with the exception of nitrite, which has a value higher than the one defined in the legislation. It was also observed that the concentrations of the elements that initially had higher concentrations rapidly decreased during the leaching process. For instance, sulfates decreased from $431 \mathrm{mg} / \mathrm{l}$ to $81 \mathrm{mg} / \mathrm{l}$, i.e., about 5 -fold. Chlorides decreased from $183 \mathrm{mg} / \mathrm{l}$ to $11 \mathrm{mg} / \mathrm{l}$, i.e., about 16-fold. In sample ISAC 5, the concentrations of all elements present were less than the leaching limit values defined in the mentioned legislation. With the simplifications and considerations presented above, it can be concluded that the leaching achieved with the lysimeter demonstrates that ISAC has no environmental or public health risks.

Table 8 presents the leaching values obtained from the 6 samples collected in the GRS lysimeter and the leaching values obtained in the laboratory, which also adopted DIN 38414-S4. These results show that most of the elements have lower concentrations in the GRS than in the ISAC.

\section{Stiffness Assessment}

The stiffness assessment of pavement performance was done by means of FWD tests with three different load levels: $20 \mathrm{kN}, 30 \mathrm{kN}$, and $47 \mathrm{kN}$. These tests were carried out periodically over 28 months. 
TABLE 7-Results of the lysimeter test in the ISAC section.

\begin{tabular}{|c|c|c|c|c|c|c|c|c|c|c|c|}
\hline Parameter, mg/l & $\begin{array}{l}\text { ISAC } 1 \\
(113.51)\end{array}$ & $\begin{array}{l}\text { ISAC } 2 \\
(248.51)\end{array}$ & $\begin{array}{c}\text { ISAC } 3 \\
(408.51)\end{array}$ & $\begin{array}{l}\text { ISAC } 4 \\
(568.51)\end{array}$ & $\begin{array}{l}\text { ISAC } 5 \\
(808.51)\end{array}$ & $\begin{array}{l}\text { ISAC 6 } 6^{\mathrm{a}} \\
(1048.51)\end{array}$ & $\begin{array}{c}\text { ISAC 7 } \\
(1583.51)\end{array}$ & $\begin{array}{c}\text { ISAC 8 } \\
(2586.51)\end{array}$ & $\begin{array}{l}\text { ISAC 9a } \\
(2711.51)\end{array}$ & $\begin{array}{l}\text { ISAC } 10^{\mathrm{a}} \\
(2836.51)\end{array}$ & $\begin{array}{l}\text { ISAC 11 a } \\
(2961.51)\end{array}$ \\
\hline pH (-) & 11.5 & 11.2 & - & - & - & - & - & - & - & - & - \\
\hline Electrical conductivity, $\mathrm{mS} / \mathrm{cm}$ & 25.6 & 2.2 & - & - & - & - & - & - & - & - & - \\
\hline Ammonium, mg N/l & $<0.13$ & $<0.13$ & - & - & - & - & - & - & - & - & - \\
\hline Adsorbable organic halogens, $\mathrm{mg} \mathrm{Cl} / \mathrm{l}$ & 0.02 & 0.03 & 0.027 & 0.016 & - & - & - & - & - & - & - \\
\hline Arsenic & $<0.002$ & $<0.002$ & - & - & - & - & - & - & - & - & - \\
\hline Cadmium & $<0.009$ & $<0.009$ & - & - & - & - & - & - & - & - & - \\
\hline Lead & $<0.06$ & $<0.06$ & - & - & - & - & - & - & - & - & - \\
\hline Cyanide & $<0.05$ & $<0.05$ & - & - & - & - & - & - & - & - & - \\
\hline Chloride & 183 & 136 & 103 & 51 & 58 & 66 & 9 & 7 & 19 & 20 & 11 \\
\hline Copper & 0.076 & 0.15 & 0.11 & 0.06 & 0.04 & 0.08 & $<0.025$ & $<0.025$ & 0.03 & $<0.025$ & 0.03 \\
\hline Carbon organic total & 18.9 & 29.8 & - & - & - & - & - & - & - & - & - \\
\hline Chromium VI & $<0.05$ & 0.17 & 0.14 & 0.1 & 0.08 & 0.06 & $<0.05$ & $<0.05$ & 0.1 & $<0.05$ & 0.1 \\
\hline T. chromium & 0.3 & 0.3 & 0.18 & 0.06 & 0.05 & 0.08 & $<0.05$ & $<0.05$ & 0.08 & $<0.05$ & 0.06 \\
\hline Phenol & 0.02 & 0.04 & $<0.01$ & 0.02 & 0.07 & 0.09 & 0.09 & 0.09 & 0.02 & 0.01 & 0.08 \\
\hline Fluoride & 1.19 & 0.02 & 0.82 & 0.79 & 0.28 & 0.43 & 0.26 & 0.23 & 0.35 & 0.3 & 0.32 \\
\hline Mercury & $<0.001$ & $<0.001$ & - & - & - & - & - & - & - & - & - \\
\hline Nickel & $<0.04$ & $<0.04$ & - & - & - & - & - & - & - & - & - \\
\hline Nitrite & 14 & 0.09 & 0.11 & 4 & 2 & $<0.04$ & 1 & 1 & $<0.04$ & 0.5 & $<0.04$ \\
\hline Sulphate & 431.28 & 411 & 170 & 106 & 135 & 175 & 58 & 24 & 98 & 64 & 81 \\
\hline Zinc & $<0.006$ & $<0.006$ & - & - & - & - & - & - & - & - & - \\
\hline
\end{tabular}

Note: The symbol $<$ (less than) represents the limit of quantification of the method used.

${ }^{\mathrm{a}} \mathrm{S} a \mathrm{mples}$ of leachate produced by rain water (total volume collected in the lysimeter was $2961.5 \mathrm{l}$ ). 
TABLE 8-Results of the lysimeter test in the granite residual soil (GRS) section.

\begin{tabular}{|c|c|c|c|c|c|c|c|}
\hline $\begin{array}{l}\text { Parameter, } \\
\mathrm{mg} / \mathrm{l}\end{array}$ & GRS-Lab & $\begin{array}{l}\text { GRS } 1 \\
(1251)\end{array}$ & $\begin{array}{l}\text { GRS 2 } \\
\left(\begin{array}{lll}200 & 1\end{array}\right)\end{array}$ & $\begin{array}{l}\text { GRS } 3 \\
(3251)\end{array}$ & $\begin{array}{l}\text { GRS4 } \\
(4501)\end{array}$ & $\begin{array}{c}\text { GRS5 } \\
(5751)\end{array}$ & $\begin{array}{c}\text { GRS } 6 \\
(7001)^{\mathrm{a}}\end{array}$ \\
\hline $\mathrm{pH}(-)$ & 8.4 & 8.0 & - & - & - & - & - \\
\hline Electrical conductivity, $\mathrm{mS} / \mathrm{cm}$ & 0.14 & 0.20 & - & - & - & - & - \\
\hline Ammonium, mg N/l & $<0.13$ & $<0.13$ & - & - & - & - & - \\
\hline Adsorbable organic halogens, $\mathrm{mg} \mathrm{Cl} / \mathrm{l}$ & 0.016 & 0.01 & 0.024 & $<0.01$ & - & - & - \\
\hline Arsenic & 0.01 & $<0.002$ & - & - & - & - & - \\
\hline Cadmium & $<0.01$ & $<0.009$ & - & - & - & - & - \\
\hline Lead & $<0.1$ & $<0.06$ & - & - & - & - & - \\
\hline Cyanide & $<0.05$ & $<0.05$ & - & - & - & - & - \\
\hline Chloride & $<1$ & 8.3 & 7 & 6 & 7 & 3 & 5 \\
\hline Copper & 0.42 & $<0.025$ & - & - & - & - & - \\
\hline Carbon organic total & 2.8 & 2.6 & $<1.0$ & $<1.0$ & - & - & - \\
\hline Chromium VI & $<0.05$ & $<0.05$ & - & - & - & - & - \\
\hline T. chromium & $<0.05$ & $<0.05$ & - & - & - & - & - \\
\hline Phenol & 0.05 & 0.04 & 0.04 & 0.02 & $<0.01$ & 0.07 & $<0.01$ \\
\hline Fluoride & $<0.1$ & 0.04 & 0.13 & 0.13 & 0.04 & 0.02 & 0.02 \\
\hline Mercury & $<0.01$ & $<0.001$ & - & - & - & - & - \\
\hline Nickel & 0.09 & $<0.04$ & - & - & - & - & - \\
\hline Nitrite & 0.04 & $<0.04$ & - & - & - & - & - \\
\hline Sulphate & 161 & 83 & 25 & 11 & $<10$ & 64 & 12 \\
\hline Zinc & 0.22 & 0.421 & 0.13 & 0.03 & 0.02 & 0.09 & 0.04 \\
\hline
\end{tabular}

Note: The symbol $<$ (less than) represents the limit of quantification of the method used.

${ }^{\mathrm{a}}$ Total volume collected in the lysimeter was 7001.

Figure 13 shows the maximum deflections as a function of the applied load in one monitoring campaign. It is observed that for the three load levels, ISAC shows better performance than natural materials (soil and granite aggregate). Looking at the maximum deflections under $47 \mathrm{kN}$ of all the monitoring campaigns carried out in the field, ISAC shows remarkably better performance than the natural materials (soil and granite aggregate), as shown in Fig. 14.

These field results are in accordance with the results obtained in laboratory performance-based tests, which puts into question the results of the index tests. Also, in a European project [6], it was highlighted that some waste materials have better mechanical performance in the field than expected based on the results of index tests. This has been observed for natural materials and byproducts [36-38], which is more evidence of the need to change the principles of the characterization of materials by giving greater emphasis to a rational basis (mechanistic approach) rather than empirical testing. Consequently, the evaluation of material performance should be based on performance-based tests.

The mechanical classification presented in EN 13286-7 [31], which is based on performance-based tests, is much more realistic because it uses mechanical parameters to refer to the mechanical behavior of integral materials with grading and state conditions (dry density and water content), and not to a single fraction of the material, which might not be representative of the overall behavior of the material. Thus,

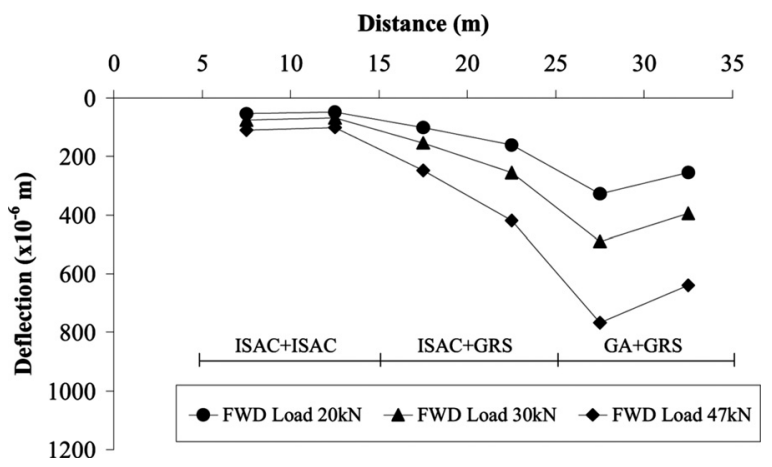

FIG. 13-Mechanical performance of pavement sections with ISAC and natural materials for different FWD loads (date: March 24, 2010). 


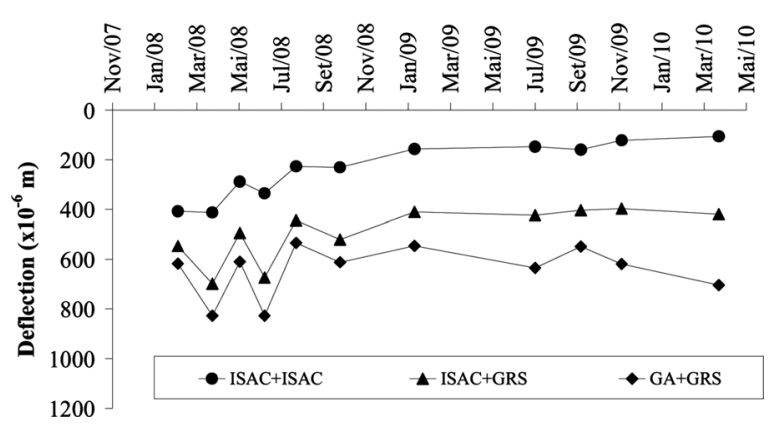

FIG. 14-Mechanical performance of pavement sections with ISAC and natural materials under $47 \mathrm{kN}$ FWD load over time.

material rankings should be based on performance-based tests in order to better classify the use of natural aggregates, and especially when classifying alternative materials.

\section{Socioeconomic Aspects: A Case Study of ISAC Application}

As with any other economical activity, potential users of recycled industrial byproducts, as owners and contractors, will be interested in their use only if the options available are economically advantageous compared to traditional solutions and if these materials are available close to the location when needed.

In general terms, the cost of construction materials depends on their price and transportation cost. As mentioned before, ISAC has recently begun to be used as a construction material. Currently, its price depends on the prices of other materials able to satisfy the designed technical requirements and on the required and produced quantities of this material. The transportation costs for placement at the job site depend on the distance and the material density. The density of ISAC is higher than those of standard aggregates, which means higher transportation costs for the same distance.

In a road construction project carried out recently in Portugal, near Lisbon, named "EN10 - Quinta do Conde section," the specifications established for the materials to be used in the subbase layer were for traditional well-graded crushed aggregates. However, the contractor and the owner studied two alternative solutions that could meet equivalent technical requirements using recycled industrial byproducts.

One of the studied alternatives was to use traditionally rejected aggregate mixtures from a limestone quarry. This quarry, located approximately $16 \mathrm{~km}$ away from the worksite, was also the origin of the technically appropriate well-graded crushed aggregate (standard material).

The other alternative was the use of ISAC, produced approximately $10 \mathrm{~km}$ away from the worksite. The price of ISAC was $€ 1 /$ ton, and the transportation cost was $€ 1 /$ ton as well. The total costs of a cubic meter placed in situ of well-graded aggregate, rejected aggregate mixture from a limestone quarry, and ISAC were $€ 11.28$, €8.81, and $€ 7.77$, respectively. Under these circumstances, it was decided that ISAC would be used as an alternative to the standard crushed aggregate for the subbase course. The subbase layer was $0.35 \mathrm{~m}$ thick, making the total needed volume of ISAC $7000 \mathrm{~m}^{3}$. During the quality control construction work, 9 plate load tests were made on top of the ISAC layer, leading to deformation modulus measurements $E V_{2}$ (French standard NF P 94-117-1 [39]) ranging from 131 to $173 \mathrm{MPa}$, with an average value of $154 \mathrm{MPa}$ and a coefficient of variation of 0.10 . These moduli were much larger than those established by the construction specifications (minimum value of $80 \mathrm{MPa}$ ) based on the use of natural materials, confirming once more the better mechanical performance of ISAC.

\section{Final Remarks}

This study describes the methodology used in a case study aimed at promoting the reuse of industrial byproducts, particularly processed steel slag aggregates (ISAC), as a substitute for natural aggregates or traditional materials used in transportation infrastructures and geotechnical works. It aims to contribute technically and scientifically to the application of the principles of sustainable construction. It also contributes to the preservation of natural resources and to the reduction of waste deposited in landfills.

Based on the index test results, it was shown that ISAC meets the specifications of the Portuguese Roads Administration. Furthermore, the laboratory performance-based test results demonstrate that ISAC 
has better mechanical properties (stiffness and resistance against permanent deformation) than standard base course materials. These results emphasize that Portuguese ISAC could be used in geotechnical works, particularly in transportation infrastructures (embankments, capping layers, and base courses).

This laboratory study revealed that the index test results, when applied in order to predict the mechanical performance of non-traditional materials or byproducts, must be critically discussed. It is stressed that the principles of material characterization should be changed so as to focus more on the results of performance-based test results.

In addition to the laboratory study, a full-scale field trial (road section) was performed, and field tests were carried out to evaluate ISAC mechanical and environmental performance. These test results validate the laboratory findings. In particular, they demonstrate ISAC's superior mechanical performance compared to that of natural soil and natural base course aggregates. Moreover, with regard to the environmental aspects, it is confirmed that ISAC is an inert waste in terms of leachability.

The technical data obtained in this study show that processed steel slag (ISAC) can be considered as a new construction material and, consequently, could be used in competition with natural aggregates for the construction of transportation infrastructures and other geotechnical works.

It is important to point out that the results of this study indicate that ISAC can be used by major construction companies because it is accepted by bodies such as the Portuguese Roads Administration and the National Railway Network and creates market conditions in which ISAC competes with traditional materials. This paper illustrates a case study in which a cost analysis showed that ISAC was beneficial when compared to other aggregates. As a final remark, it should be mentioned that according to the data supplied by the Portuguese ISC, the accumulated tons of Maia ISAC have already sold out, and at this time there is a lack of material for delivery. The same is expected of the Seixal ISAC, where the stock is decreasing continuously. This year, sales of ISAC already have resulted in savings of a few hundred thousand Euros.

\section{Acknowledgments}

The writers would like to thank FCT for financial support of this project (PPCDT/ECM/56952/2004) through the POCI 2010 program and for the cohesion found FEDER and a doctoral grant within company SFRH/BDE/15661/2007. Thanks are also due to António Cavalheiro, deputy manager of the Seixal Iron Steel Company (SN Seixal - Siderurgia Nacional), and to Teodoro Gomes Alho, SA, for providing information about the case study.

\section{References}

[1] Motz, H. and Geiseler, J., "Products of Steel Slags: An Opportunity to Save Natural Resources," Waste Manage., Vol. 21, 2001, pp. 285-293.

[2] Shen, W., Zhou, M., Ma, W., Hu, J., and Cai, Z., "Investigation on the Application Steel Slag-Fly Ash-Phosphogypsum Solidified Material as Road Base Material," J. Hazard. Mater., Vol. 164(1), 2009, pp. 99-104.

[3] Suer, P., Lindqvist, J., Arm, M., and Frogner-Kockum, P., "Reproducing Ten Years of Road Ageing. Accelerated Carbonation and Leaching of EAF Steel Slag," Sci. Total Environ., Vol. 407, 2009, pp. 511-518.

[4] Pasetto, M. and Baldo, N., "Experimental Evaluation of High Performance Base Course and Road Base Asphalt Concrete with Electric Arc Furnace Steel Slags," J. Hazard. Mater., Vol. 181(1-3), 2010, pp. 938-948.

[5] "Courage, Construction with Unbound Road Aggregates in Europe," project funded by the European Commission under the Transport RTD Programme of the 4th Framework Programme (1999).

[6] "Alt-Mat, Alternative Materials in Road Construction," project funded by the European Commission under the Transport RTD Programme of the 4th Framework Programme (1998/1999).

[7] "Samaris, Sustainable and Advanced Materials for Road Infrastructures," project funded by the European Commission under the Transport RTD Programme of the 5th Framework Programme (2002/ 2005).

[8] Roque, A. J., Gomes Correia, A., Fortunato, E., Pardo de Santayana, F., Castro, F., Reis Ferreira, S. M., and Trigo, L., "The Geotechnical Re-Use of Portuguese Inert Siderurgical Aggregate," 
Thirteenth Pan-American Conference on Soil Mechanics and Geotechnical Engineering, Sociedad Venezolana Geotecnia, Curran Associates, Inc., Margarita Island, Venezuela, July 16-20, 2007.

[9] Roque, A. J., Castro, F., Gomes Correia, A., Silva, S., and Cavalheiro, A., "Laboratory and Field Leaching Tests for Predicting the Environmental Impact of Portuguese Steel Slag," Sixth International Congress on Environmental Geotechnics, Datta, Srivastava, Ramana, and Shahu, Eds., McGraw Hill, New Delhi, India, Nov 8-12, 2010, Vol. 2, pp. 1166-1171.

[10] DIN 38414-S4, 1984, "Methods for the Examination of Water, Waste Water and Sludge; Sludge and Sediments (Group S)—Determination of Leachibility by Water (S4)," DIN, Berlin, Germany.

[11] EN 12457, 2002, "Characterisation of Waste_Leaching_Compliance Test for Leaching of Granular Waste Materials and Sludges," CEN, Brussels, Belgium.

[12] E LNEC 196, 1967, “Soils—Particle Size Distribution,” LNEC, Lisbon, Portugal (in Portuguese).

[13] BS 812-105.2, 1990, "Testing Aggregates-Methods for Determination of Particle Shape-Elongation Index of Coarse Aggregate," BSI, London, United Kingdom.

[14] E LNEC 199, 1967, "Soils-Sand Equivalent Test," LNEC, Lisbon, Portugal (in Portuguese).

[15] NF P 18-592, 1990, “Aggregates-Methylene Blue Test,” AFNOR, Paris, France (in French).

[16] NP 143, 1969, "Soils-Determination of Atterberg Limits," IPQ, Caparica, Portugal (in Portuguese).

[17] NP 581, 1969, "Aggregates for Mortar and Concrete-Determination of the Density and Absorption of Gravel," IPQ, Caparica, Portugal (in Portuguese).

[18] E LNEC 197, 1967, "Soils—Compactation Test," LNEC, Lisbon, Portugal (in Portuguese).

[19] E LNEC 237, 1971, “Aggregates-Test of Abrasion by Los Angeles Machine,” LNEC, Lisbon, Portugal (in Portuguese).

[20] NP EN 1097-1, 2002, “Tests for Mechanical and Physical Properties of Aggregates-Part 1. Measurement of the Resistance to Wear (Micro-Deval MDE)," IPQ, Caparica, Portugal (in Portuguese).

[21] E LNEC 198, 1967, "Soil—Determination of CBR," LNEC, Lisbon, Portugal (in Portuguese).

[22] UNE EN 1744-1, 1999, "Tests for Chemical Properties of Aggregates-Chemical Analysis," AENOR, Madrid, Spain (in Spanish).

[23] EN 13242, 2002, "Aggregates for Unbound and Hydraulically Bound Materials for Use in Civil Engineering Work and Road Construction," CEN, Brussels, Belgium.

[24] Goto, S., Tatsuoka, F., Shibuya, S., Kim, Y.-S., and Sato, T., "A Simple Gauge for Local Small Strain Measurements in the Laboratory," Soils Found., Vol. 31(1), 1991, pp. 169-180.

[25] Gomes Correia, A., Reis Ferreira, S. M., Roque, A. J., and Cavalheiro, A., "Processed Portuguese Steel Slags-A New Geomaterial," Eighth International Conference on the Bearing Capacity of Roads, Railways, and Airfields, Erol Tutumluer and Imad L. Al-Qadi, Eds., University of Illinois at Urbana - Champaign, Champaign, Illinois, USA, June 29-July 2, 2009, CRC Press, Vol. 1, pp. 197-204.

[26] Hoque, E. and Tatsuoka, F., “Anisotropy in the Elastic Deformation of Materials," Soils Found., Vol. 38(1), 1998, pp. 163-179.

[27] EN 13289-7, 2004, "Unbound and Hydraulic Bound Mixtures-Part 7. Cyclic Load Triaxial Test for Unbound Mixtures," CEN, Brussels, Belgium.

[28] XP P 18-540, 1990, “Aggregate-Definition, Compliance, Specifications,” AFNOR, Paris, France (in French).

[29] Paute, J. L., Hornych, P., and Benaben, J. P., "Mechanical Behavior of Unbound Granular Materials under Repeated Load Triaxial Testing," Bulletin de Liaison de Laboratories Central des Ponts et Chaussées, No. 190, 1994, pp. 27-38 (in French).

[30] NF P 98-129, 1994, "Untreated Gravel-Definition, Composition and Classification” AFNOR, Paris, France (in French).

[31] EN 13286-7, 2004, "Unbound and Hydraulically Bound Mixtures - Part 7. Cyclic Load Triaxial Test for Unbound Mixtures," CEN, Brussels, Belgium.

[32] Gomes Correia, A., Anhdan, L. Q., Koseki, J., and Tatsuoka, F., "Small Strain Stiffness under Different Isotropic and Anisotropic Stress Conditions of Two Granular Granite Materials," Advanced Laboratory Stress-Strain Testing of Geomaterials, F. Tatsuoka, S. Shibuya and R. Kuwano, Eds., A. A. Balkema/Swets \& Zeitlinger, B. V., Lisse, The Netherlands, 2001, pp. 209-215.

[33] Reis Ferreira, S. M., 2010, "Environmental and Mechanical Behaviour of Granular Materials. Application to National Steel Slags," Ph.D. thesis, University of Minho, Portugal (in Portuguese). 
[34] Coronado, O. G., 2005, "Study of Mechanical Behaviour of Compacted Unsaturated Unbound Granular Materials under Cyclic Loading," Ph.D. thesis, Ecole Centrale, Paris (in French).

[35] Iwasaki, T., Tatsuoka, F., and Takagi, Y., "Shear Moduli of Sands Under Cyclic Torsional Shear Loading," Soils Found., Vol. 18(1), 1978, pp. 39-50.

[36] Grégoire, C., Dethy, B., Detry, J., and Gomes Correia, A., "Characterizing Natural and Recycled Granular Materials for (Sub)Base Layers of Roads by Cyclic Triaxial Testing," Eighth International Conference on the Bearing Capacity of Roads, Railways, and Airfields, Erol Tutumluer and Imad L. Al-Qadi, Eds., University of Illinois at Urbana - Champaign, Champaign, Illinois, USA, June 29-July 2, 2009, CRC Press, Vol. 1, pp. 215-223.

[37] Gomes Correia, A. and Lacasse, S., "Technical Session 2e: Marine \& Transportation Geotechnical Engineering," Proceedings of the Sixteenth International Conference on Soil Mechanics and Geotechnical Engineering, ISSMGE, Osaka, Japan, 12-16 September 2005, Millpress, Rotterdam, The Netherlands, pp. 1707-1710.

[38] Reid, J. M., 2001, "The Use of Alternative Materials in Road Construction," www.viastrade.it/letteratura/materiali/TRL_TO_ALT_MAT.pdf (Last accessed 14 Dec 2009).

[39] NF P 94-117-1, 2000, "Soils: Investigation and Testing-Formation Level Bearing Capacity. Part 1. Plate Test Static Deformation Module (EV2),” AFNOR, Paris, France (in French). 